\title{
Changes in Beef Consumption and Retailing Competitiveness in Brazil: A Rapid Appraisal
}

\author{
Danilo R.D. Aguiar \\ Department of Rural Economy, Federal University of Viçosa, Viçosa, \\ MG 36571-000, Brazil. E-mail: danilo@mail.ufv.br
}

\author{
Andrea Lago da Silva \\ Department of Production Engineering, Federal University of São Carlos, \\ C.P. 676, São Carlos, SP 13565-905, Brazil. \\ E-mail: deialago@power.ufscar.br
}

\begin{abstract}
This paper analyzed the competitiveness of beef retailing in Brazil. We carried out a rapid appraisal by means of extensive usage of secondary information, key informant semistructured interviews and direct observation all around the country. We found that beef has been losing competitiveness to other meats in part because of price disadvantage and in part because of marketing inefficiencies. The critical points are: the intermittent quality, unhealthy image and high price of beef, the low level of income of most consumers, inept enforcement of safety regulations, and failing vertical coordination. An important outcome of this study is that most of the problems faced by retailers do not depend only on them. However, retailers need to play a dominant role in dealing with these issues because they represent the most organized segment of the Brazilian beef system. [Econ-Lit citations: L 660, L 810]. (C) 2002 Wiley Periodicals, Inc.
\end{abstract}

\section{INTRODUCTION}

The pattern of beef consumption has changed considerably over the last two decades in Brazil. Behind such change, there have been several structural adjustments as well. Economic theory states that consumers adjust their purchases responding to changes in income, prices or preferences; all these factors have been changing in Brazil. Per capita income has increased, at least until 1997, and low-income consumers have had real income increments due to decreasing inflation. Moreover, the prices of all types of meat, especially chicken, have been decreasing year by year. Two other very important effects result from changes in consumer preferences: middle and high income consumers have become more concerned about health and have consumed more low-fat meat; and convenience has become more and more important to Brazilian households.

Besides the direct impact of prices, income and preferences, there have also been at least two major institutional changes affecting the beef market. The first was the Real Plan, a macroeconomic program set out in June 1994, which drastically reduced Brazil's historical inflation and promoted trade liberalization. The second was a new regulation 
regarding beef marketing composed of laws numbered 145 and 307. Roughly, these laws determine conditions for animal slaughtering, beef handling, transportation and marketing. Under the new laws, all beef cuts should be traded at retail free of bone, packaged in plastic bags, and labeled with information regarding slaughter date and location, sex of the animals, etc.

In this paper we examine how quickly and profoundly beef consumption has changed and assess the competitiveness of beef retailing in Brazil. This paper is organized into five sections. In the next section we analyze briefly the main transformations we identified in the Brazilian beef distribution system: the changes in consumer behavior; the changes in beef consumption for consumers of different groups of income; and the changes in retailing. In Section 3 we present our empirical methods to evaluate competitiveness. In Section 4 we report and analyze our results and in Section 5 we conclude the paper.

\section{CHANGES IN CONSUMER BEHAVIOR AND RETAILING IN BRAZIL}

\subsection{Consumer Behavior}

Lazzarini-Neto et al. (1996) point out the six main attributes of Brazilian beef in which consumers have focused: (a) palatability, perceived when eating and related to tenderness, flavor, etc.; (b) appearance, perceived when buying, through color, consistency, etc.; (c) convenience, related to product form (sliced, precooked, etc.); (d) nutrition, related to the contents of vitamins, minerals and proteins, requiring very specific consumer information to be monitored; (e) health, mainly associated with concerns regarding heart diseases; and (f) food safety, related to the transmission of diseases due to inappropriate handling and storage of the product. In addition, price still is a very important attribute, though it has not been as important as before for medium and high-income consumers.

Among the attributes mentioned above, some have affected more substantially the Brazilian beef distribution system. Consumers have somehow followed the consumption patterns identified in more developed countries, stressing convenience, food safety and health concerns. Regarding convenience, the time available for cooking has shrunk since most families today have both parents working outside the home. This fact plus the availability of new electronic machines like microwaves and freezers have driven the demand toward ready-to-eat food. Likewise, the habits of eating away from home and buying take-out food have spread to a large extent. There is still another dimension of convenience, not highlighted by Lazzarini-Neto et al. (1996), that reflects on the choice of points of purchasing. Today consumers are more likely to buy in places where they can find a large array of products, since concentrating purchases in a specific store is a great timesaver. Consequently, supermarkets have surpassed butcher shops as the main point of beef sales in Brazil.

The new pattern of beef distribution in Brazil assigns $65 \%$ of the total beef to supermarkets (including hypermarkets and supercenters), restaurants, hotel and industrial restaurants; 30\% to butcher shops; and 5\% to meat boutiques ${ }^{1}$ (Gazeta Mercantil, 1998).

\footnotetext{
${ }^{1}$ Meat boutiques are stores selling high quality and expensive meat products mainly to high-income consumers. They are often located in shopping malls of big cities. In addition to meat, they commonly sell some kinds of exotic and imported products. Their focus is on marketing services such as special bags, food preparation and consumer information.
} 
TABLE 1. Per Capita Consumption of Beef in 1987 and 1996 for Different Levels of Income

\begin{tabular}{lccr}
\hline $\begin{array}{l}\text { Levels of Income } \\
\text { Number of } \\
\text { Minimum Wages) }\end{array}$ & 1987 & 1996 & $\begin{array}{r}\text { Change } \\
(\%)\end{array}$ \\
\hline Until 2 & 12.31 & 12.73 & 3.37 \\
2 to 3 & 14.39 & 18.31 & 27.25 \\
3 to 5 & 15.79 & 18.54 & 17.39 \\
5 to 6 & 18.32 & 20.13 & 9.86 \\
6 to 8 & 19.49 & 21.78 & 11.75 \\
8 to 10 & 21.15 & 22.67 & 7.20 \\
10 to 15 & 23.34 & 24.46 & 4.80 \\
15 to 20 & 25.78 & 26.00 & 0.85 \\
20 to 30 & 26.05 & 36.94 & 41.78 \\
More than 30 & 31.67 & 28.06 & -11.40 \\
Total & 21.27 & 22.85 & 7.42 \\
\hline
\end{tabular}

Source: IBGE (1999).

Besides convenience, increasing concerns with product quality and safety have driven consumer purchases from street markets and butcher shops to supermarkets and meat boutiques, since the latter two types of stores are more likely to control product quality and are under tighter public inspection than the others. As the data above show, beef boutiques are not so important to beef marketing yet. The strongest trend is toward supermarkets. Supermarkets have become more important to beef retailing and meat marketing has become more important to supermarkets as well; around of $12 \%$ of the sales of Brazilian supermarkets are due to meat products (Gazeta Mercantil, 1998), which are often used as a way to attract consumers to buy additional products.

\subsection{Income Effects and Competition Among Different Cuts of Beef}

Per capita annual beef consumption of Brazilian households in the nine major metropolitan areas have been relatively stable, increasing only around of $1.5 \mathrm{~kg}$ (from $21.27 \mathrm{~kg}$ to $22.85 \mathrm{~kg}$ ) between 1987 and 1996. Despite that, when we focus on different income levels (Table 1) we see that there have been deep changes within every income group. All groups had consumption increments, with the exception of the richest group, which reduced its beef consumption by more than $11 \%$. The group with income ranging from 20 to 30 times the minimum wage had the highest increase in consumption.

It is important to note that the Brazilian per capita income, calculated by Parity of Purchase Power, increased 45\% (from US\$ 2,614.6 to US\$ 3,804.0) during the period referred to in Table 1 . In this context, the reduction in beef consumption by high-income consumers suggests that beef is an inferior good for such consumers. Other explanations for this fact rely on changes in consumer behavior. As we have seen, high-income consumers have been particularly concerned about eating healthy food and have reduced their consumption of beef. Also, the data presented in Table 1 include only at-home consumption, while one of the biggest trends in consumer behavior is toward consumption away from home. The increase in beef consumption by low- and middle-income consum- 
ers is strongly associated with their income growth; for such consumers, beef and other meats have higher income elasticities. ${ }^{2}$

There has also been competition among different cuts of beef. Table 2 shows that the consumption of cow belly ${ }^{3}$ has decreased for most income groups, with the exception of the group with incomes between two and three times the minimum wage. It is also possible to verify that consumers with low and intermediate levels of income substituted high quality for low quality beef. Though no estimate has been done yet, it is very reasonable to suppose that the income elasticities of better quality beef is higher than those of worse quality beef, as reflected in the data shown in Table 2.

\subsection{Retailing Changes}

We have seen that supermarkets have become the most important outlet of beef sales in Brazil. This fact by itself implies in higher concentration of beef retailing, since the supermarket sector is more concentrated than the traditional beef retail outlets. Moreover, the mergers, acquisitions and constructions of new stores experienced by Brazilian supermarkets have turned this sector even more concentrated.

Table 3 shows, by means of three different indexes, how market concentration has increased among Brazilian supermarkets from 1992 to 1998. Unfortunately, we did not find data for all supermarkets covering the whole decade and needed to mix data regarding the top 20, the top 300 and all supermarkets. All indexes showed an impressive increase in market concentration in 1998. The differences appeared in 1995; data including all supermarkets showed an increase in concentration that year, as the others showed a decrease. Despite the differences in data source, which probably affected the results, Table 3 suggests that not only the top 5 but also the top 20 and the top 300 increased their market share in 1995; this explains the reduction in CR5 among the top 20 and top 300 that year. If we focus on what happened after 1994, we can use the most accurate measure, the CR5 calculated with data of all supermarkets. This measure showed an upward movement with two jumps, one in 1995 and another in 1998. An important part of this trend is related to investments of foreign supermarket chains. The first among them was the French chain Carrefour, which has been in Brazil since 1970 but has increased its investments substantially over the last few years. More recently, supermarket chains from Portugal (Sonae and Grupo Gerônimo Martins), The Netherlands (Ahold) and U.S. (Walmart) have arrived.

Data regarding mergers and acquisitions in Brazilian retail are provided by KPMG (1999). For the years between 1994 and 1999, they reported, sequentially, two, zero, two, nine, 13 and 22 mergers and acquisitions, showing an upward trend after 1995. Moreover, KPMG (1999) showed that the retail sector in Brazil ranks second in terms of investments in mergers and acquisitions, just behind the recently privatized sector of telecommunications.

Though the CR5's presented in Table 3 were very impressive, they understated the concentration ratio of regional and local markets because they were based on national

\footnotetext{
${ }^{2}$ For example, Furtuoso (1981) found meat income elasticities of 0.19, for consumers earning more than 10 times the Brazilian official minimum wage; 0.46, for people earning between 5 and 10 times the minimum wage; and 1.22 , for people earning less than 5 times the minimum wage.

${ }^{3}$ Cow belly refers to several low-cost beef parts, such as stomach, liver, kidney, etc.
} 


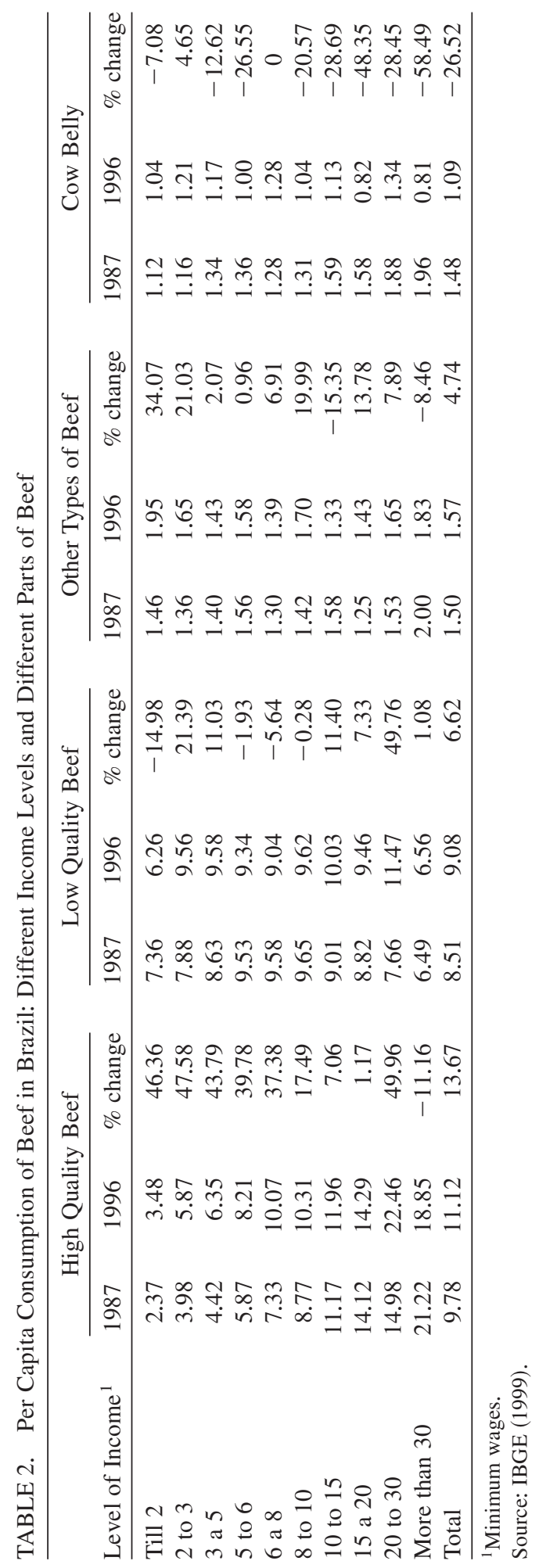


TABLE 3. Concentration Rate of the Top 5 (CR5) Supermarkets in Brazil, in Relation to the Top 20, Top 300 and all Supermarkets

\begin{tabular}{cccc}
\hline Year & $\begin{array}{c}\text { CR5 Among } \\
\text { the Top 20 } \\
(\%)\end{array}$ & $\begin{array}{c}\text { CR5 Among } \\
\text { the Top 300 } \\
(\%)\end{array}$ & $\begin{array}{c}\text { CR5 } \\
\text { Among All } \\
(\%)\end{array}$ \\
\hline 1992 & 64.55 & 37.62 & - \\
1993 & 62.69 & 36.30 & - \\
1994 & 64.90 & 37.23 & 23 \\
1995 & 58.69 & 33.80 & 28 \\
1996 & 59.84 & 35.66 & 26 \\
1997 & 61.90 & 37.36 & 27 \\
1998 & 71.80 & 48.15 & 33 \\
\hline
\end{tabular}

Source: KPMG (1999) for columns 2 and 3; ABRAS (Brazilian Association of Supermarkets) for column 4.

data. ${ }^{4}$ Thus, the Brazilian retail is very concentrated and has gotten more and more concentrated. This new reality has affected the bargain between retailers and processing companies. Traditionally, low levels of concentration and internationalization of retailers allowed the processors to control the strategies related to beef marketing, deciding about products and prices. More recently, as in other countries, the Brazilian retailers have become the leaders of the marketing process. This is especially true in the case of beef marketing, given the disorganization of most of the slaughter sector. The supermarket leadership is explained by several strategies adopted by large supermarkets, such as centralization of purchases, national merchandising, and usage of advanced systems of control and logistics (Engel et al., 1995; Anderson et al., 1997; and Kumar, 1997). Furthermore, the regime of free trade adopted by Brazil after the Real Plan has allowed retailers to make use of imported products whenever they wish and some international supermarket chains, or Brazilian chains with international partners, have had exclusive access to suppliers of other regions and countries.

\section{METHODS}

Van Duren et al. (1991) defined competitiveness as the ability to profitably gain and maintain market share in domestic or international markets, and pointed to the three main approaches to study competitiveness: neoclassic economics, which draws inferences from changes in market share; the industrial organization approach, which shows that competitiveness increases with rivalry and decreases with cooperation; and the strategic management approach, which deals with factors that promote or impede the competitiveness of an industry in a dynamic sense. Since none ot the approaches is sufficiently broad to analyze all the dimensions associated with competitiveness, Van Duren et al. (1991) proposed a framework combining all of them. In their framework, they used profits and mar-

\footnotetext{
${ }^{4}$ This same bias was verified in the U.S. by Cotterill (1999); the retail national CR5 for 1998, 33.2\% was comparable to the Brazilian, while all but 12 among 94 local markets (chosen among the top 100) had four-firm concentration above $60 \%$.
} 
ket share as indicators of competitiveness and chose seven general competitiveness drivers (productivity, technology, products, inputs and costs, concentration, demand conditions, and linkages) which determine the degree of competitiveness in an industry. Additionally, the competitiveness drivers were divided into competitiveness factors and every factor was classified according to its degree of controllability, since some of them can be controlled by firms, others by government, others are almost controllable (they can be affected, but not controlled) and still others are uncontrollable. The indicators and factors were then evaluated by means of quantitative and qualitative information.

\subsection{Indicators of Competitiveness}

We based our approach mainly on Van Duren et al. (1991). Due to the lack of data and to the particularities of the sector we analyzed, we needed to make some adjustments. First, our definition of competitiveness focused only on the domestic market, since we were studying the beef retail sector. As indicators of competitiveness, we used beef market share in relation to other meats, meat price ratios, and the Retailer Gross Margin Selling Price Rate (from now on referred as Retailer Margin). Beef market shares and price ratios show how this product has performed vis-à-vis their main substitutes. The Retailer Margin measures the value earned by retailers in the process of agricultural marketing value divided by the retail price. Thus the Retailer Margin shows the retailers share of the price paid by consumers. It includes marketing costs (costs of transport, storage, handling, promotion, etc.) and profits as well. The Retailer Margin was calculated as follows. Using monthly wholesale prices for three different parts of beef in the State of São Paulo, published by IEA, we calculated, by means of the coefficients presented by Canto (1986), a series of monthly wholesale average prices. Dividing a series of retail average beef prices of São Paulo city (also published by IEA) by the calculated wholesale average prices, we ended up with an index that can be interpreted like the Retailer Margin: an increase in retail price relative to the wholesale price means that the Retailer Margin increased. ${ }^{5}$

\subsection{Explanatory Variables and Major Assumptions}

Figure 1 presents the relationship between the explanatory variables and the indicators of competitiveness. Inside every box, the drivers of competitiveness are in capital letters and the competitiveness factors are indicated by arrows. The oval frame represents competitiveness and its indicators are also pointed by arrows. As one can see, competitiveness is supposed to result from the competitiveness drivers.

After every factor of competitiveness we present our classification of controllability for that factor. Since we dealt with just one market segment, we needed to split the factors controllable by firms into two groups: "controllable by retail firms" and "controllable by other firms." Retail firms control most of the factors, but some are controllable by other firms, some by the government and some are almost controllable. The drivers "technology" and "market relations" as well as the factors "beef," "product variety," "traceability" and "product diversification" were all classified into two categories of controllability because they depend on firms of other market segments (livestock farmers, slaughter-

\footnotetext{
${ }^{5}$ The Retailer Margin is $[(\mathrm{Pr}-\mathrm{Pw}) / \mathrm{Pr}]=1-(\mathrm{Pw} / \mathrm{Pr})$, where $\mathrm{Pr}$ is retail price and $\mathrm{Pw}$ is wholesale price. So, when $(\mathrm{Pr} / \mathrm{Pw})$ increases the Retailer Margin also increases.
} 


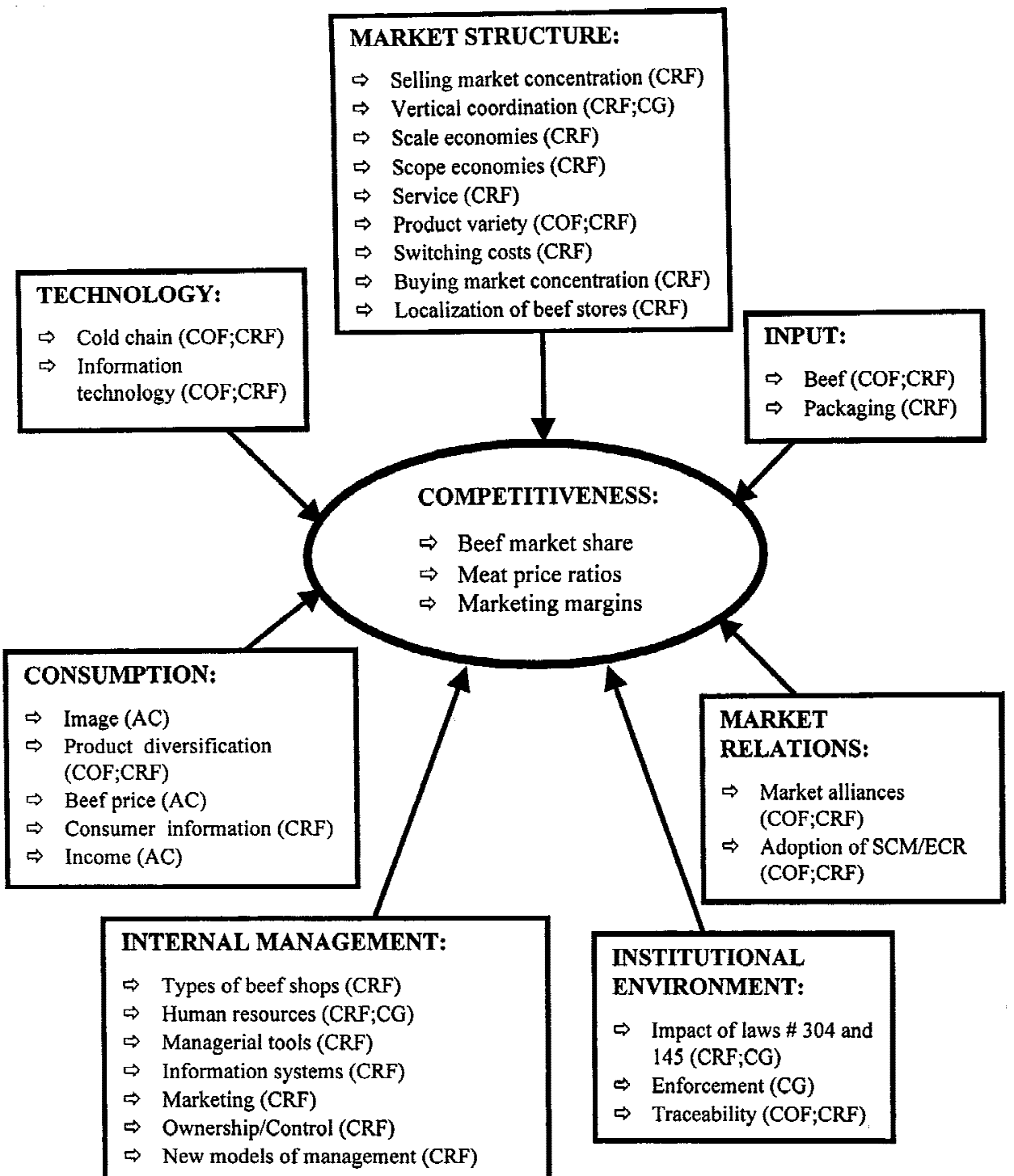

Figure 1 Relationship between competitiveness indicators and competitiveness drivers and factors, including the controllability degrees represented by: $\mathrm{COF}=$ controllable by other firms; $\mathrm{CF}=$ controllable by retail firms; $\mathrm{CG}=$ controllable by government; $\mathrm{AC}=$ almost controllable; and $\mathrm{U}=$ uncontrollable.

houses, etc.) as well as on retail firms. "Product image" and "beef price" are almost controllable because they can be affected by the whole commodity system, but not controlled by any one firm or government agency. "Income" is considered almost controllable because the government has some power to interfere in this variable. Other three factors, "vertical coordination," "human resources" and "impact of laws 304 and 145" are con- 
trolled by retail firms and by the government as well. Finally, the factor "enforcement" is controlled only by the government.

\subsection{Data Collection Methods, Weight and Ranking Techniques}

Recognizing the complexity of the Brazilian beef distribution system and the lack of quantitative data to measure all the competitiveness factors, we carried out a rapid appraisal by means of extensive usage of secondary information, key informant semistructured interviews and direct observation all around the country. Rapid appraisal methods have long been used to evaluate market efficiency in developing countries ${ }^{6}$ because they have several advantages, such as: cost less than other formal methods; can be quickly completed; are better than formal methods to deal with complex socioeconomic systems; and are very flexible, in the sense that they allow evaluators to explore new issues that may not have been anticipated. Among their disadvantages are: they have limited validity, because they depend greatly on the abilities of evaluators in choosing correct samples and in avoiding biases; and they do not provide quantitative information. ${ }^{7}$ In order to minimize some of the deficiencies associated to the method, we adopted several protective procedures. Before starting the interviews, we carried out an exhaustive review of secondary data and information regarding our subject and wrote a preliminary report, which was discussed with the other researchers involved in the project. This phase allowed us to determine what the main issues were in order to organize the interviews and to identify the key informants to be interviewed. After conducting the interviews, we wrote a new version of the report and discussed it again with the other researchers. The last step to validate our results was to present them to representatives of retail firms, class associations and other private and public institutions, at a workshop organized by the sponsors of this study. The results presented here are, therefore, the outcome of a process of filtering that involved several experts and market agents.

The results of the rapid appraisal allowed us to grade every competitiveness factor by means of a scale, type "Likert," varying from "very favorable," when the factor showed significant positive contribution, to "very unfavorable," if there were serious obstacles to competitiveness. As intermediary categories, we established "favorable," "neutral" and "unfavorable." In order to proceed with a graphic analysis, the scale was transformed in values that varied progressively, in unitary intervals, from -2 , for a "very unfavorable" evaluation, to +2 , for "very favorable." The quantitative combination of every factor's grade to generate an evaluation for each driver of competitiveness required the attribution of relative weights based on the importance of every factor to its specific driver.

One more consideration is necessary. Recognizing the diversity of the Brazilian beef distribution system and aiming to simplify the analysis, we split it into two subsystems with different competitive characteristics: modern and traditional. The modern subsystem, from now on called subsystem A, included meat boutiques, supermarkets and hypermarkets. In terms of product characteristics, this subsystem focuses on consumers more concerned with quality and convenience. Conversely, the traditional subsystem, called subsystem B, is composed of the less competitive traditional retailers (butcher shops and

\footnotetext{
${ }^{6}$ See Morris (1995) and Holtzman et al. (1995) for instance.

${ }^{7}$ For more advantages and disadvantages of rapid appraisal methods, see Kumar (1993) and USAID (1996).
} 
street markets). These distribution firms serve consumers more concerned with prices than quality.

\section{ANALYSIS AND DISCUSSION OF THE RESULTS}

\subsection{Indicators of Competitiveness}

Let us start with the indicators of competitiveness. Brazilian meat per capita consumption has been around 70 to $75 \mathrm{~kg}$ per year over the 1990's. Beef still is the most eaten meat (around $40 \mathrm{~kg}$ ) in the country, followed by chicken $(25 \mathrm{~kg})$ and pork $(10 \mathrm{~kg})$. However, this pattern has changed significantly more recently. From 1990 to 1998, beef consumption has decreased approximately $20 \%$ in relation to pork and almost $40 \%$ in relation to chicken (Fig. 2). An ordinary explanation for this phenomenon relies on changes in relative prices. Actually, several empirical studies have found that beef consumption is somehow affected by changes in pork and chicken prices. For instance, Fernandes et al. (1989) found demand cross price elasticities of 0.1 between chicken and beef, and 0.19 between pork and beef. Conversely, Bachi and Barros (1992) found that beef demand was not affected by chicken prices, but only by pork prices; their estimated demand cross price elasticities between pork and beef was 0.3 in the short run, and 0.64 in the long run. All these estimates, however, used data running till the beginning of the 80 's, probably understating the more recent effects.

In spite of the empirical studies cited above, when we look at the relative prices of beef, chicken and pork (Figs. 3 and 4), we see that this variable per se does not explain what is happening in all meat markets. From 1975 to 1997, beef prices have increased more than $50 \%$ in relation to chicken prices, but have remained almost steady in relation to pork prices.

Looking at the Retailer Margin, Figure 5 shows clearly that, after a fall in the beginning of the 1990's, the Retailer Margin became relatively steady until the middle of 1994 (beginning of the Real Plan), but has increased about of $30 \%$ since then. This result needs

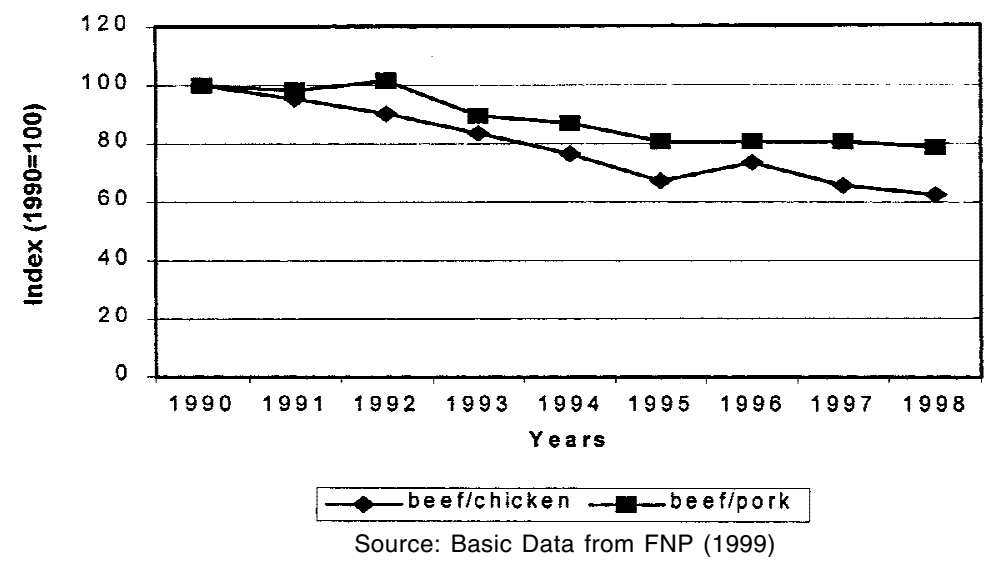

Figure 2 Index of consumption of beef divided by consumption of chicken and pork in Brazil, 1990-1998. 


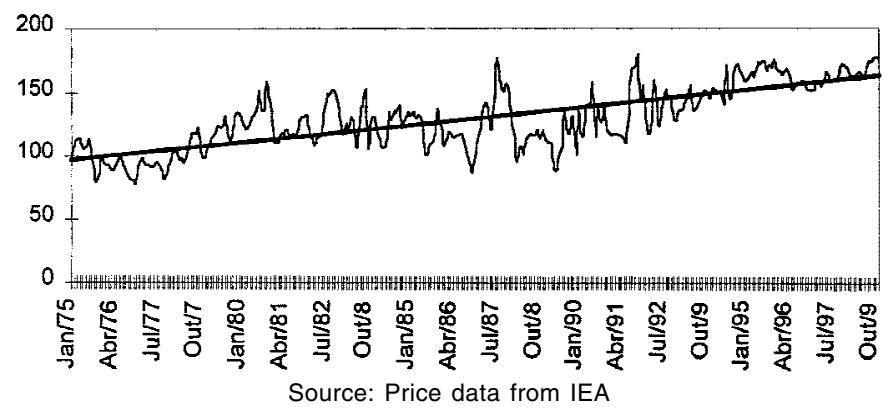

Figure 3 Index of beef price over chicken price (January $1975=100$ ).

to be analyzed carefully because an increase in the Retailer Margin does not necessarily imply a profit increase. Theoretically, the Retailer Margin can also increase due to an increase in marketing costs, an increase in input prices or an addition of new services. However, an increase in marketing costs does not seem to have occurred in Brazil. Between 1994 and 1997, the overvaluation of the Brazilian currency associated with trade liberalization and inflation reduction depreciated prices of most inputs. Moreover, no significant addition of new services in beef marketing has taken place and retailers have even gained sale economies, which should have reduced their unitary marketing costs. So the most likely explanation for the Retailer Margin increase is profit increase, which is also backed by the increase in retail concentration.

The results above provide mixed conclusions about the competitiveness in beef retailing. The increase in profits may suggest an increase in competitiveness, but the loss of market share to chicken and pork suggest that the beef sector has not been competitive. There are at least two facts behind such results. First, the Retailer Margin calculation used data of the whole beef retail sector and consequently overstates subsystem B competitiveness. Second, the increase in profits might be exclusively the outcome of bargain power, and not of innovative behavior. That means that the beef retail sector has not behaved in a way that would invert the unfavorable trend for beef products.

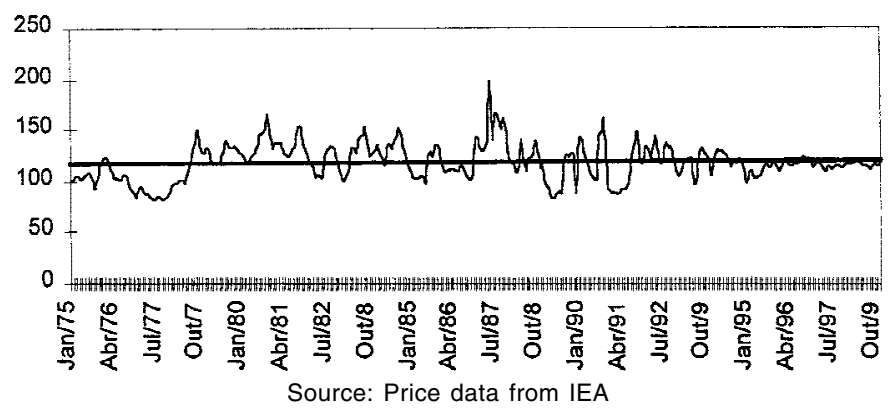

Figure 4 Index of beef price over pork price (January $1975=100$ ). 


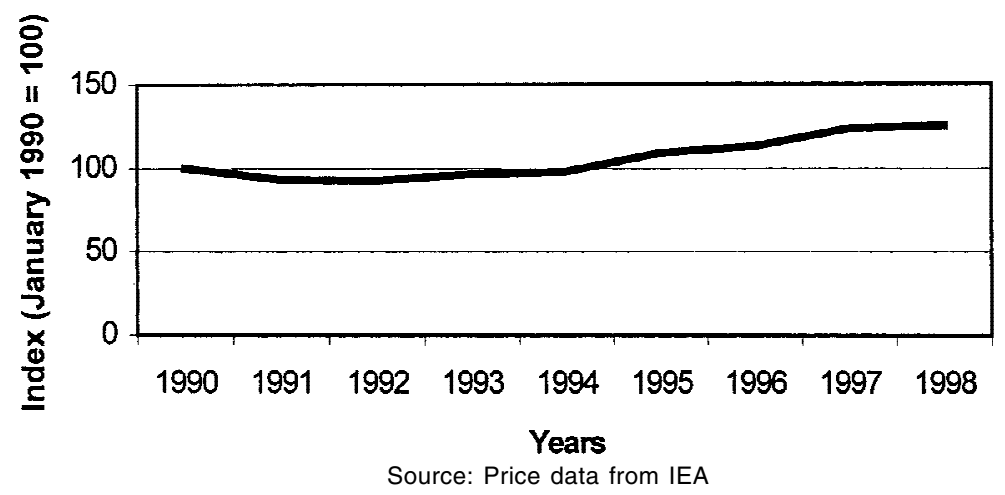

Figure 5 Retailer Gross Margin Selling Price Rate of beef.

\subsection{Competitiveness Drivers and Factors}

Turning to the evaluation of the competitiveness factors, Table 4 reports the grades of every factor as well as their weights. Following the table from the top, we see that the technologies used in the Brazilian beef distribution system could be improved, since this factor has negatively impacted the system's competitiveness. The cold chain, the most important technological component in beef marketing, is unfavorable even for subsystem A; both subsystems are affected by inappropriate conditions of transportation and intermediate storage, but the traditional subsystem is still more affected because even at retail stores the product is not stored at adequate temperatures. Additionally, information technology has not been used sufficiently by the economic agents of subsystem A and is practically ignored by those of subsystem B.

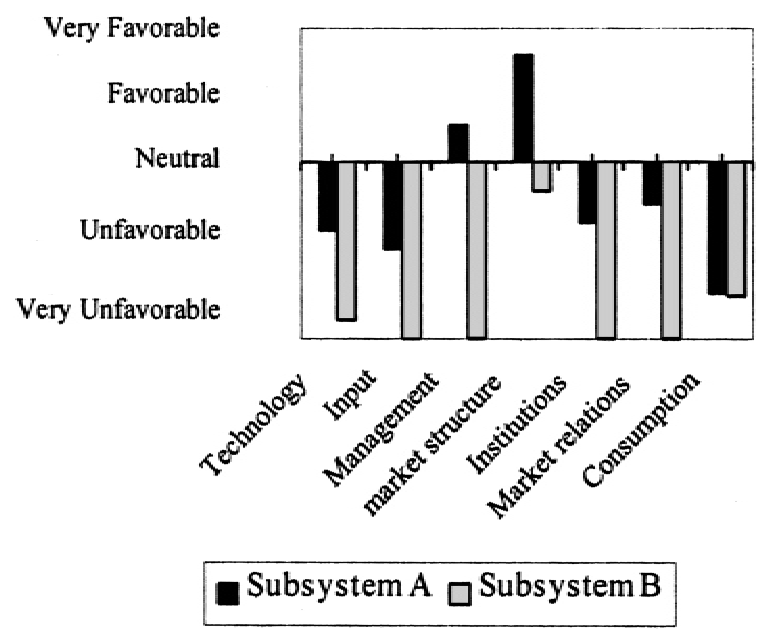

Figure 6 Aggregated impacts of the drivers of competitiveness on the traditional (B) and modern (A) subsystems. 
TABLE 4. Evaluation of the Competitiveness Factors of the Brazilian Beef Distribution System

\begin{tabular}{|c|c|c|c|c|c|c|c|c|}
\hline \multirow[b]{2}{*}{$\begin{array}{l}\text { Drivers and Factors of } \\
\text { Competitiveness }\end{array}$} & \multicolumn{5}{|c|}{ Controllability $^{\mathrm{a}}$} & \multicolumn{2}{|c|}{ Evaluation $^{\mathrm{b}}$} & \multirow[b]{2}{*}{ Weight } \\
\hline & $\mathrm{COF}$ & CRF & $\mathrm{CG}$ & $\mathrm{AC}$ & $\mathrm{U}$ & $\begin{array}{l}\text { Subsystem } \\
\text { A }\end{array}$ & $\begin{array}{c}\text { Subsystem } \\
\text { B }\end{array}$ & \\
\hline \multicolumn{9}{|l|}{ Technology } \\
\hline Cold chain & $\mathrm{X}$ & $\mathrm{X}$ & & & & $\mathrm{U}$ & VU & 0.8 \\
\hline Information Technology & $\mathrm{X}$ & $\mathrm{X}$ & & & & $\mathrm{N}$ & $\mathrm{U}$ & 0.2 \\
\hline Subtotal & & & & & & & & 1.0 \\
\hline \multicolumn{9}{|l|}{ Input } \\
\hline Beef & $\mathrm{X}$ & $\mathrm{X}$ & & & & $\mathrm{U}$ & VU & 0.6 \\
\hline Packaging & & $\mathrm{X}$ & & & & $\mathrm{U}$ & VU & 0.4 \\
\hline Subtotal & & & & & & & & 1.0 \\
\hline \multicolumn{9}{|l|}{ Market structure } \\
\hline Selling Market Concentration & & $\mathrm{X}$ & & & & VF & $\mathrm{U}$ & 0.10 \\
\hline Vertical Coordination & & $\mathrm{X}$ & $\mathrm{X}$ & & & $\mathrm{N}$ & $\mathrm{U}$ & 0.15 \\
\hline Scale Economies & & $\mathrm{X}$ & & & & $\mathrm{F}$ & $\mathrm{U}$ & 0.10 \\
\hline Scope Economies & & $\mathrm{X}$ & & & & VF & $\mathrm{U}$ & 0.15 \\
\hline Service & & $\mathrm{X}$ & & & & $\mathrm{N}$ & VF & 0.15 \\
\hline Product Variety & $\mathrm{X}$ & $\mathrm{X}$ & & & & VF & $\mathrm{U}$ & 0.15 \\
\hline Switching Costs & & $\mathrm{X}$ & & & & $\mathrm{F}$ & $\mathrm{F}$ & 0.5 \\
\hline Buying Market Concentration & & $\mathrm{X}$ & & & & VF & $\mathrm{U}$ & 0.10 \\
\hline Localization of Beef Stores & & $\mathrm{X}$ & & & & $\mathrm{F}$ & $\mathrm{F}$ & 0.05 \\
\hline Subtotal & & & & & & & & 1.0 \\
\hline \multicolumn{9}{|l|}{ Internal management } \\
\hline Types of Beef Shops & & $\mathrm{X}$ & & & & $\mathrm{F}$ & VU & 0.10 \\
\hline Human Resources & & $\mathrm{X}$ & $\mathrm{X}$ & & & $\mathrm{F}$ & VU & 0.20 \\
\hline Managerial Tools & & $\mathrm{X}$ & & & & $\mathrm{F}$ & VU & 0.20 \\
\hline Information Systems & & $\mathrm{X}$ & & & & $\mathrm{F}$ & VU & 0.10 \\
\hline Marketing & & $\mathrm{X}$ & & & & $\mathrm{N}$ & VU & 0.20 \\
\hline Ownership/Control & & $\mathrm{X}$ & & & & $\mathrm{U}$ & VU & 0.10 \\
\hline New Models of Management & & $\mathrm{X}$ & & & & $\mathrm{U}$ & VU & 0.10 \\
\hline Subtotal & & & & & & & & 1.0 \\
\hline \multicolumn{9}{|l|}{ Institutional Environment } \\
\hline Impact of Laws 304 and 145 & & $\mathrm{X}$ & $\mathrm{X}$ & & & $\mathrm{F}$ & VU & 0.30 \\
\hline Enforcement & & & $\mathrm{X}$ & & & $\mathrm{VU}$ & VU & 0.50 \\
\hline Traceability & $\mathrm{X}$ & $\mathrm{X}$ & & & & $\mathrm{N}$ & VU & 0.20 \\
\hline Subtotal & & & & & & & & 1.0 \\
\hline \multicolumn{9}{|l|}{ Market relations } \\
\hline Market Alliances & $\mathrm{X}$ & $\mathrm{X}$ & & & & $\mathrm{N}$ & VU & 0.50 \\
\hline Adoption of SCM/ECR ${ }^{\mathrm{c}}$ & $\mathrm{X}$ & $\mathrm{X}$ & & & & $\mathrm{U}$ & VU & 0.50 \\
\hline Subtotal & & & & & & & & 1.0 \\
\hline \multicolumn{9}{|l|}{ Consumption } \\
\hline Image (health issues) & & & & $\mathrm{X}$ & & VU & $\mathrm{U}$ & 0.30 \\
\hline Product Diversification & $\mathrm{X}$ & $\mathrm{X}$ & & & & $\mathrm{U}$ & $\mathrm{U}$ & 0.15 \\
\hline Beef Price & & & & $\mathrm{X}$ & & VU & VU & 0.20 \\
\hline Consumer Information & & $\mathrm{X}$ & & & & $\mathrm{U}$ & VU & 0.10 \\
\hline Income & & & & $\mathrm{X}$ & & $\mathrm{U}$ & $\mathrm{VU}$ & 0.25 \\
\hline Subtotal & & & & & & & & 1.0 \\
\hline
\end{tabular}

${ }^{\mathrm{a}} \mathrm{COF}=$ controllable by other firms; $\mathrm{CF}=$ controllable by retail firms; $\mathrm{CG}=$ controllable by government; $\mathrm{AC}=$ almost controllable; $\mathrm{U}=$ uncontrollable.

${ }^{\mathrm{b}} \mathrm{F}=$ favorable; $\mathrm{VF}=$ very favorable; $\mathrm{N}=$ neutral; $\mathrm{U}=$ unfavorable; $\mathrm{VU}=$ very unfavorable.

${ }^{\mathrm{c}}$ Refers to supply chain management and Efficient Consumer Response. 
The driver "input" has "beef" and "packaging" as its most important factors (since other inputs, such as labor, were included in other categories) and we consider it unfavorable for subsystem A and very unfavorable for subsystem B. In general, beef does not reach retail at a regular pattern of quality, since the farm production systems are very diverse. This is even worse for subsystem B, where safety problems can arise because of the inefficient public inspection system. Regarding packaging, while in the modern supermarkets the beef cuts are packaged in plastic bags, in subsystem B we found even newspapers being used as bags. Though the supermarkets' bags are superior, they are not as convenient as the ones used to market chicken, since they do not allow consumers to check adequately the products' quality and do not provide appropriate consumer information (only product validity has been provided).

When we look at the driver "market structure" we must remember that our focus is on competitiveness from the point of view of the retail firms, which means that some factors that are positively related to competitiveness might impact negatively the social welfare. Table 4 shows that there is no one factor unfavorable for subsystem A, whereas most factors are unfavorable for subsystem B. Market concentration is very favorable for subsystem A because the high concentration verified in this subsystem allows firms to exercise some market power, improving their competitiveness. Alternatively, the small market share of every retail store in subsystem B makes this system less powerful. Following the same rationale, subsystem A enjoys advantages in terms of scale and scope economies and also in terms of oligopsonistic power when buying beef from the slaughterhouses. The only advantage of subsystem B over A is found in services, since the former is able to provide personal services.

The factors related to "internal management" are all very unfavorable for subsystem B and mostly favorable for subsystem A. Critical issues for both subsystems are ownership/control and adoption of new models of management. Most of the retail stores, especially in subsystem B, are managed by owners or owners' family members, and not by professional managers. As a result, new practices of management are rarely or slowly adopted.

Regarding the "institutional environment," the most recent event is the launching of laws numbered 304 and 145. The requirements of these laws in terms of product handling will reinforce the advantage of subsystem A, since the firms of this subsystem are already adopting processes like the ones proposed by the new laws. The most important institutional factor, however, is safety inspection and law enforcement. Federal inspection is required only for products traded out of their states of origin; state inspection applies to products traded between cities into the same state; and municipal inspection deals with trade inside a city. The problem is that the federal agencies assigned to inspect product quality and to enforce the new laws have faced strong budget cuts, while most of the states and municipalities are not equipped to satisfactorily accomplish their duties. Traceability is another aspect that differentiates subsystem A from B. Even though Brazilian consumers do not require traceability yet, subsystem A is more likely to adopt such a mechanism when it is considered necessary.

The driver "market relations" is not favorable to any of the subsystems. Though some of the biggest supermarket groups have gone through some sort of contractual agreements with feedlots and slaughterhouses in Brazil, these initiatives have not involved large quantities of beef and the results have not yet been stimulating. Similarly, while some firms in subsystem A have already started using some methods of supply chain 
management, such as Efficient Consumer Response (ECR), ${ }^{8}$ these mechanisms are totally absent in subsystem B. Lack of interest in a better vertical coordination of the system, which still predominates among retailers and slaughterhouses, affects negatively the competitiveness of both subsystems. A better coordination could improve, for example, the quality of the product, a critical point in beef retailing.

The last driver of competitiveness is "consumption." The most important factor of this driver is "product image," because consumers have become accustomed to the idea that red meat consumption causes heart disease. This aspect affects more intensely consumers of subsystem A, who have access to more information. "Level of income," on the other hand, affects the consumers of subsystem B more, since they are generally poorer than consumers of subsystem A. High price and lack of a larger diversity of products are as negative for subsystem A as for subsystem B, and explain some of the disadvantages of beef in relation to chicken.

Figure 5 aggregates the factors of competitiveness by means of their evaluation and weights. The results showed more clearly what the most important drivers were for every subsystem. Subsystem B had negative effects in all drivers. This means that the firms operating in subsystem B need to radically change their procedures in almost all drivers in order to remain in business. However, even subsystem A has much to change in order to become competitive. The most important issue in subsystem A is "consumption," where the main problems are high prices and unfavorable image, both almost controllable by the firms. However, retailers have better conditions than the other firms to affect this driver. "Input" is the second in terms of negative impacts on competitiveness of subsystem A. In this driver, the quality of beef depends not only on retail firms but also on firms of other market segments. Conversely, packaging is under control of the firm. In the third most important drive, "technology," improvements depend on both retail and other firms. The fourth most important driver, "institutional environment," depends more on government, since the main factor is enforcement. The last negative driver, inappropriate vertical coordination, can be improved by retailers if they initiate new practices of supply chain management, but also depend on firms of other market segments.

\section{CONCLUDING REMARKS}

Some characteristics of Brazilian consumers were very apparent through this analysis: high income consumers have reduced their consumption of beef at home, whereas low and middle income consumers have consumed more beef; and supermarkets have become the most important retail outlets for beef. All these trends are expected to continue, since they are based on new consumer patterns associated with income growth and the spread of information: So the relevant question is whether the beef retail is responding adequately to the new situation.

We conclude that the traditional subsystem will not last for long, particularly in the most developed areas of the country, because this subsystem is not able to conform to new regulations and consumer requirements. The modern subsystem also has to improve to cope with its functions. Particularly, retail stores should look for better ways to coordinate the vertical relationships throughout the chain, adopting new processes such as ECR and other initiatives. This measure can make the system more efficient, improving

\footnotetext{
${ }^{8}$ For a good synthesis of ECR and its impact on food retailing, see King and Phumpiu (1997).
} 
beef quality and reducing prices. Another issue to be stressed by retailers is the management of the cold chain, which should be improved for both public health and marketing purposes. Furthermore, associations representing retailers and other members of the beef chain should invest in advertisement to improve the image of beef among consumers and government agencies should improve the enforcement of the several laws which aim to regulate the market.

An important outcome of this study is that most of the problems faced by retailers do not depend only on them, but on other firms and government agencies as well. However, retailers need to play a dominant role in dealing with these issues because they represent the most organized segment of the Brazilian beef system, and they are more aware of consumption trends than slaughterhouses and livestock farmers.

\section{ACKNOWLEDGMENTS}

This paper is based on part of a larger study that analyzed the efficiency of the whole Brazilian beef system, funded by the Brazilian Confederation of Industry (CNI-IEL), Brazilian Confederation of Agriculture (CAN) and Brazilian Service to Support Small and Medium Business (SEBRAE). Some adjustments needed to be made in relation to the main report because we focused on only one segment in this paper. However, these results did not contradict the results of the main report. The authors are grateful for helpful comments from Carlos Arthur da Silva, Mario Batalha, Paulo Furquim de Azevedo, Hildo Souza Filho, Alberto Rezende, Carlos Augusto Fontes, Lucio Gomide, Ronaldo Perez, and the research assistants, when the methodology of this research was set out and during the elaboration of the main report. We also would like to acknowledge the helpful comments of an anonymous reviewer. Errors remain the responsibility of the authors.

\section{REFERENCES}

Anderson, E., Day, G.S., \& Rangan, V.K. (1997). Strategic channel design. Sloan Management Review, 38, 59-69.

Bachi, M.R.P., \& Barros, G.S.A.C. (1992). Demanda de carne bovina no mercado brasiliero. Revista de Economia e Sociologia Rural, 30, 83-96.

Canto, W.L. (1986). Sistema ponderal de conversões e determinação de margens de comercialização. Campinas, ITAL, Série Estudos Econômicos-Alimentos Processados, \#22.

Cotterill, R.W. (1999). Continuing concentration in food industries globally: Strategic challenges to an unstable status quo. In Gomes, M., Costa, F. (Eds.). Desequilíbrio econômico \& agronegócio. Universidade Federal de Viçosa, Viçosa, MG, Brazil.

Engel, J.F., Blackwell, R.D., \& Miniard, P.W. (1995). Consumer behavior. Orlando, Florida: Drydem Press.

Fernandes, S.G., Paniago, E., \& Lima, J.E. (1989). Análise de alternativas de políticas para o setor de carnes no Brasil. Revista de Economia Rural, 27, 437-459.

FNP. (1999). Anualpec_-Anuário da Pecuária Brasileira. FNP Consultoria \& Comércio, São Paulo.

Furtuoso, M.C.O. (1981). Distribuição de renda e consumo de alimentos no estado de São Paulo. M.S. Thesis. University of São Paulo, Piracicaba, SP, Brazil.

Gazeta Mercantil. (1998). Análise setorial—a indústria de carne. São Paulo: Gazeta Mercantil. Volume I.

Holtzman, J.S., Lichte, J.A., \& Tefft, J.F. (1995). Using rapid appraisal to examine coarse grain processing and utilization in mali. In Scott, G.J. (Ed.). Prices, products, and people: analyzing ag- 
ricultural markets in developing countries, pp. 43-72. Boulder, Colorado: Lynne Rienner Publishers, Inc.

IBGE. (1999). Pesquisa de orçamentos familiares. Instituto Brasileiro de Geografia e Estatística. Available at www.ibge.org.br.

IEA. Informações Econômicas. São Paulo, Instituto de Economia Agrícola, several issues.

King, R.P., Phumpiu, P.F. (1997). ECR: a revolution in the retail food system. Minnesota Agricultural Economist, 688, 1-4.

KPMG. (1999). Fusões e Aquisicões. Corporate Finance, São Paulo, SP, Brazil.

Kumar, K. (Ed.). (1993). Rapid appraisal methods. Washington, DC: World Bank.

Kumar, N. (1997). Create trust, not fear, in manufacturer-retailer relationships. Perspectives for Managers. Available at the International Institute for Management Development site: www.imd.ch/pub/pfm_9703.html.

Lazzarini-Neto, S., Lazzarini, S.G., \& Pismel, F.S. (1996). Pecuária de corte: a nova realidade e perspectivas do agribusiness. São Paulo, SP, Brazil: Lazzarini \& Associados.

Morris, M.L. (1995). Rapid reconnaissance methods for diagnosis of sub-sector limitations: maize in Paraguay. In Scott, G.J. (Ed.). Prices, products and people: analyzing agricultural markets in developing countries, pp. 21-42. Boulder, Colorado: Lynne Rienner Publishers, Inc.

USAID. (1996). Using rapid appraisal methods. USAID Center for Development Information and Evaluation, Performance Monitoring and Evaluation TIPS, \#5. Available at www.usaid.org.

Van Duren, E., Martin, L., \& Westgren, R. (1991). Assessing Competitiveness of Canada's Agrifood Industry, Canadian Journal of Agricultural Economics, 39, 727-738.

Danilo R.D. Aguiar is an associate professor in the Department of Rural Economy, Federal University of Viçosa, Viçosa, MG 36571-000,Brazil.E-mail: danilo@mail.ufv.br. He received his B.S. (1985) in agronomy, and his M.S. (1990) and Ph.D. (1994) in agricultural economics from the University of São Paulo (Brazil). His research interests include industrial organization, agribusiness, pricing, and futures markets.

Andrea Lago da Silva is an associate professor in the Department of Production Engineering, Federal University of São Carlos, C. P. 676, São Carlos, SP 13565-905, Brazil. E-mail: deialago@power.ufscar.br. She received her B.S. in business (1990) and M.S. in production engineering (1993) from Federal University of Santa Catarina (Brazil) and her Ph.D. in Business (1999) from the University of São Paulo (Brazil). Her research interests include distribution channels, supply chain management, information technology and ECR, and agribusiness. 